\title{
Corrigendum: Prediction of Maximum Flood Inundation Extents with Resilient Backpropagation Neural Network: Case Study of Kulmbach
}

\section{OPEN ACCESS}

Edited and reviewed by: Mingfu Guan,

The University of Hong Kong,

Hong Kong

${ }^{*}$ Correspondence

Qing Lin

tsching.lin@tum.de

Specialty section: This article was submitted to

Hydrosphere,

a section of the journal Frontiers in Earth Science

Received: 10 May 2021 Accepted: 26 May 2021 Published: 16 July 2021

Citation:

Lin Q, Leandro J, Wu W, Bhola P and Disse M (2021) Corrigendum:

Prediction of Maximum Flood Inundation Extents with Resilient Backpropagation Neural Network:

Case Study of Kulmbach.

Front. Earth Sci. 9:707556.

doi: 10.3389/feart.2021.707556
Qing Lin*, Jorge Leandro, Wenrong Wu, Punit Bhola and Markus Disse

Department of Civil, Geo and Environmental Engineering, Technical University of Munich, Munich, Germany

Keywords: hazard, maximum inundation extent, artificial neural network, Resilient backpropagation, urban flood forecast

\section{A Corrigendum on:}

Prediction of Maximum Flood Inundation Extents With Resilient Backpropagation Neural Network: Case Study of Kulmbach

by Lin Q, Leandro J, Wu W, Bhola P and Disse M (2020) Prediction of Maximum Flood Inundation Extents With Resilient Backpropagation Neural Network: Case Study of Kulmbach. Front. Earth Sci. 8: 332. doi:10.3389/feart.2020.00332

In the original article, there was a mistake in that Figures 1-11 and Tables 1-4 were published as supplementary material. The authors would like to move all figures and tables to the main article and remove the supplementary material to improve readability.

The authors apologize for this error and state that this does not change the scientific conclusions of the article in any way. The original article has been updated.

Copyright $\odot 2021$ Lin, Leandro, Wu, Bhola and Disse. This is an open-access article distributed under the terms of the Creative Commons Attribution License (CC BY). The use, distribution or reproduction in other forums is permitted, provided the original author(s) and the copyright owner(s) are credited and that the original publication in this journal is cited, in accordance with accepted academic practice. No use, distribution or reproduction is permitted which does not comply with these terms. 